\title{
複数施設の選択利用を前提とした図書館配置計画のモデル的検討 \\ 一選択利用を促す地方都市における図書館計画に関する研究 2 - LIBRARIES' LOCATION MODELS BASED ON USERS' SELECTING ACTIVITIES \\ -A study on the planning of rural libraries according to selecting activities 2-
}

\author{
丁 圓*, 今井正 次** \\ Yuan DING and Shoji IMAI
}

\begin{abstract}
This paper dicusses the arrangement planning of libraries in regional areas, based on encouraging users' selecting activies. We try to build a selection model and analyze the spread of service areas and the sphere of selecting activities. Comparing with previous research further, we summarize the conclusions as follows: (1) It is worthy to note that in the areas where selecting activities can be permitted, the service area becomes larger than the model based on setting up single-library-using as the planning premise. (2) Although the service area differs in collection-of-books of a library, if the characteristic libraries have been arranged every $7 \mathrm{~km}-10 \mathrm{~km}$, service efficiency becomes the highest according to selection model. (3)The sphere to which selecting activities are easy to take place maybe differs in many different areas, and various situations need to be examined in detail now, but as a methodology, it is clearly clarified on theory that this method based on selecting activities is effective for arrangement planning.
\end{abstract}

Keywords: library, selecting activities, model, service area, situation of selecting fullness, arrangement planning 図書館、選択利用、モデル、サービス圈域、選択充実度、配置計画

\section{1.はじめに 研究の背景}

卵形理論などの単独施設利用を計画前提とした利用・配置モデルは いろいろ提案されている。その中で、グラビティモデルでみたよう に、近さが図書館利用の主な要因として一定の半径ことに図書館 （分館）を分散的に配置する手法注1）と、クリスタラーモデルのよう に地域図書館 (分館) と地域中心館 (中央館) 注 2) $の$ 段階的に構成す る配置論を結論としたものが多い。しかし生活構造の都市化により農 村地域においても都市的行政サービスの重要性が增している。モー夕 リゼーションにより生活圈域が広域化し、住民はより高度なサービス を求めて多様な利用活動を行っている。前報文1)では、複数の図書館 を使い分けて利用している現象（以下:選択利用）に着目し、利用者 の多様化した利用要求を捉えた。利用者が単なる利用距離の影響を受 けて近傍の施設に引き寄せられる利用と、高いサービス水準を求めて 遠方にある大規模施設の利用の SB 現象的利用パターンだけでなく、 蔵書規模・利用距離・空間環境・立地環境などの図毒館サービスの特 色によって選択利用していることを明らかにした。図書館は知的社会 生活の拠点としての役割を果たすべきだと考えると、単なる蔵書冊数 だけを指標としてサービス圈域を規定する既存配㯰論は必ずしも利用 者の多様化した利用要求を満たすことができないだろう。

ここで選択利用というキーワードを採用するのは、単独施設利用へ
の考察に比べてより利用者の多様な潜在的要求の分析が可能になり、 また地域住民にとって選択利用できるという意味で、必ずしも蔵書冊 数の豊富な大規模図書館に頼ることもなく、あるいは高密度な施設立 地に頼ることもなく、図書館のサービス水準を確保できることを目指 しているためである。

\section{2. 研究の目的と方法}

\section{2-1. 研究の目的}

本報の目的は、複数施設の選択利用を計画前提とした配置モデを 構筑し、既存の地域施設配置計画論に新機軸を提出することを目標と している。具体的には次のような目的を設定する。

(1) 選択利用が起こりうる圈域を探り出す。

ここには、図書館間の直線距離と図書館サービスの特色により選択 利用の出現率の高い圈域を求め、2次元座標空間に図示し、配置モデ ルを概念的に構築する。

（2）選択利用に基づく配置モデルについてその有効性を評価する。 図書館配置計画の課題である、サービス圈域とサービス水準の視点 を中心に評価する。

(3)既存の単独館利用を計画前提とした図書館配置計画に用いられ てきた計画手法 (均質的分散配置論・段階的構成配置論)の限界を見

\footnotetext{
* 三重大学サテライト・ベンチャー・ビジネス・ラボラトリー 講師 (中核的研究機関研究員) - 博士 (工学)

** 三重大学工学部建築学科 教授・王博
}

SVBL. Researcher, Mie University, Ph. D

Prof., Dept. of Architecture, Faculty of Engineering, Mie University, Dr. Eng. 
極め、課題の整理と提案を行う。

\section{2-2. 研究の方法}

次の方法で研究を進める。

（1）前報で対象とした岐皁県の「大垣地区」と三重県の「津地区」 （計 14 図書館）は、分館を持たず周辺市町村に整備された複数の図書 館を使い分けている地区である。研究対象地区における図書館の広域 的構成を偏らなく選定するため、今回は中央館と分館の図殸館システ ムをもつ静岡県「浜松地区」(表-1) に着目し、浜松市と䋏接した浜 北市・細江町・竜洋町の 2 市 2 町で相互貸出サービスを行った 6 館を 新たに研究対象として加える。よって本報では延べ3地区計 20 図書 館の来館者アンケート調疽によって分析を進める。

(「大垣地区」と「津地区」の調㚗概要は前報を参照)

（2）前報と同じ方法で複数館利用の選択形態を整理し、選択形態別 に2 図書館までの距離区分によってそれそれ累稳し分析することによ り、複数の選択利用が起こる可能性の高い圈域を探り出す。

(3)選択利用に基づく図書館配置モデルを構筑し、図書館間の距離 や図䟧館サービスの特性により、モテルのサービス圈域と選択利用圈 域の変動をシミュレーションし評価する。

(4) 均質的分散配置と段階的構成配置を用いて、同じ方法でサービ ス圈域と選択利用範囲の変動をシミュレーションする。選択利用モデ ルと比較した上で提案を行い、図書館配膡計画論としてまとめる。

\section{2-3. 用語定薪}

（1）距離：（特に説明のない場合は）直線距離と定義する。具体的 には、利用者の利用距離は居住地 (町丁字の人口重心) から図書館ま での直線距離で、困書館間の距離は 2 圀書館の所.在地間の直線距離と なる。直線距離を指標として用いるのは既存研究成果との比較するた めでもあり、地形や来館時間の不確定な要素を省くことができ、理論 上で検証しやすいためである。

（2）サービス面積 : 図昌館サービスを受けている圈域の面積をさ す。その面穦（サービス面積）は地域の住民に図書館サービスの提供 を評価する指標とする。

（3）選択利用面穔：複数の図書館を選択利用できる圈域面積をさ す。選択利用圈域は、利用者にとって利用可能な図書館が多く、広域 における図急館サービス水準を評価する指標とする。

（4）選択充実度 : サービス面䅡に対して選択利用面穞の割合とす る。図書館サービスの充実性を評価する指標とする。

\section{3.選択利用の起こりうる圈域}

前報と同様に選択された $\mathrm{A}$ 館・B 館の 2 図書館を距離と蔵書冊数で それそれ比較し、〈近小・遠大〉・〈近大・遠小〉・〈等小・等大〉・〈近同・ 避同〉・〈等同〉の 5 つの選択形態 ${ }^{\text {注 3) }}$ に整理する。また表-2 の示し たように、例えば〈近小・遠大〉では、〈近小〉（相対的近い小規模 館）までの利用距離を $\{0 \sim 1.5 \mathrm{~km}\}\{1.5 \sim 3.0 \mathrm{~km}\}\{3.0 \sim 6.0 \mathrm{~km}\}\{6.0$ $\sim 12.0 \mathrm{~km}\}\{12.0 \mathrm{~km} \sim\}$ に区分し、〈遠大〉（相対的遠い大規模館）ま での利用距離を $\{1.5 \sim 3.0 \mathrm{~km}\}\{3.0 \sim 4.5 \mathrm{~km}\}\{4.5 \sim 8.0 \mathrm{~km}\}\{8.0 \sim$ $12.0 \mathrm{~km}\}\{12.0 \mathrm{~km} \sim\}^{\text {注 4) }}$ に区分し、近小〉と〈遠大〉のそれそれの 距離区分を組み合わせて距離区分ことに利用者数の累穔を〈近小・遠 大の全利用者数で除してパーセンテージ化し、分析を進める。

\section{3・1選択形態からみた選択利用の圈域}

3 地区合計（表 -2 上段を参照）の傾向からみると、
表-1 調㚗对象図書館と調育概要

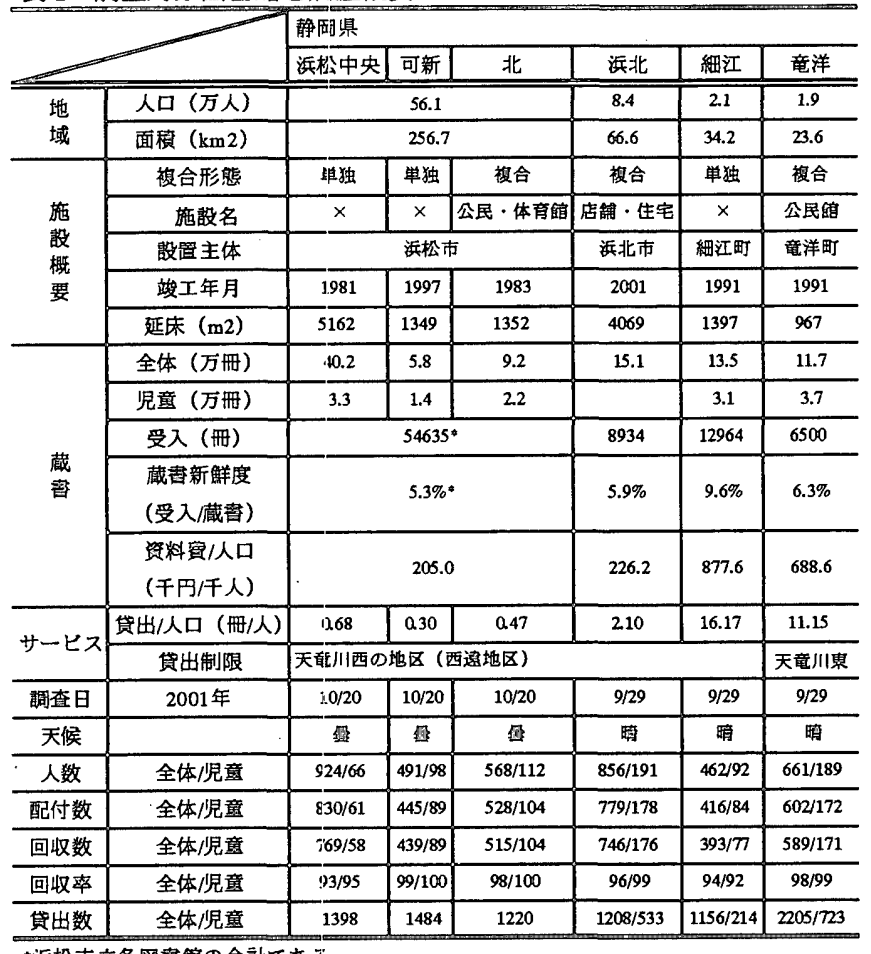

の浜松市立各図畵館の合計であう。

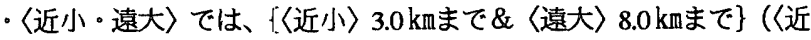
小〉の利用距離 $3 \mathrm{~km}$ まで、かつ〈遠大〉の利用距離 $8.0 \mathrm{~km}$ 等で）の利用者 数の累樌は〈近小・遠大〉全利用者の $48 \%$ となり、その中で、\{〈近小〉 $1.5 \sim 3.0 \mathrm{~km} \&$ 〈遠大〉 $4.5 \sim 8.0 \mathrm{~km}$ \} の利用者数の累積は $15 \%$ と最も多 い。また〈近小〉までの利用者数の累積は $3.0 \mathrm{~km}$ まで近小・遠大〉 全利用者の $70 \%$ を超えている。〈遠大〉までの利用者数の累積は

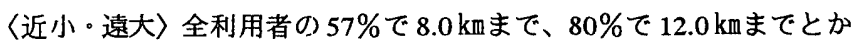
なり延びている傾向が見られる。つまり〈近小・遠大〉では、〈遠大〉 までの距離的影響は最も受けにくいと考えられる。

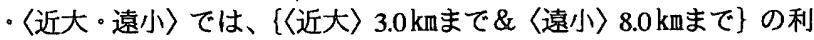
用者累積は $60 \%$ となり、その中で \{〈近大〉 $1.5 \sim 3.0 \mathrm{~km} \&$ 〈遠小〉 4.5 $\sim 8.0 \mathrm{~km}\}$ の利用者数の累瀆は $15 \%$ と最も多い。\{〈近大〉 $1.5 \mathrm{~km}$ まで \&〈遠 小〉 $8.0 \mathrm{~km}$ まで は $34 \%$ と多く見られる。また〈近大〉までの利用者 数の累積は $3.0 \mathrm{~km}$ まで近大・遠小〉全利用者の $70 \%$ を超えており、 〈遠小〉までの利用者数の累積は〈近大・遠小〉全利用者の $72 \%$ $8.0 \mathrm{~km}$ までとなっている。〈近小・遠大〉に比べ近い図書館までの距離がよ り近い。つまり、〈遠小〉までの距離は $8.0 \mathrm{~km}$ 付近にとどまっている 傾向があると考えられる。

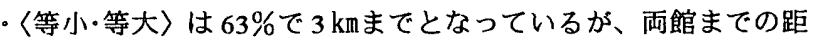
離とも $\{3.0 \sim 6.0 \mathrm{~km}\}$ であれば、 $27 \%$ と多く見られる。つまり、等 距離（両館までの距離差 $1.5 \mathrm{~km}$ 以下）の場合では、両館までの距離が $6.0 \mathrm{~km}$ 以下であれば、選択利用が可能であると考えられる。

\section{3-2 地区別にからみた鼬択利用の圈域}

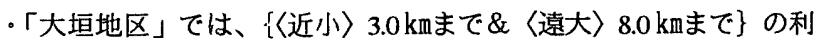
用者数の累積は $32 \%$ と三地区で最も低いが、〔〈近小〉0〜 $1.5 \mathrm{~km} \& 〈$ 遠

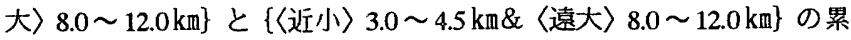
積はそれそれ全利用者の $13 \%$ と $12 \%$ となり、三地区で最も高い割合 が見られる。つまり「大垣地区」では、〈遠大〉までの利用者数の累 
表-2 選択形態別の距離構成

\begin{tabular}{|c|c|c|c|c|c|c|c|c|c|c|c|}
\hline & \multicolumn{8}{|c|}{ 〈近小・潒大〉 } & \\
\hline \multirow{2}{*}{\multicolumn{2}{|c|}{$\begin{array}{l}\text { 近小の距離 } \\
(\mathrm{km})\end{array}$}} & \multicolumn{5}{|c|}{ 逃大の距離 $(\mathrm{km})$} & \multicolumn{2}{|c|}{ 計 } & \multirow{2}{*}{$\begin{array}{l}\text { 近大の距離 } \\
(\mathrm{km})\end{array}$} & \multicolumn{2}{|c|}{ 邉小の距離（km } \\
\hline & & $\sim 3.0$ & $\sim 4.5$ & $\sim 8.0$ & $\sim 12$. & $12.0 \sim$ & 实数 & 割合 & & $\sim 3.0$ & $\sim 4.5$ \\
\hline \multirow{6}{*}{$\begin{array}{l}\text { 三地 } \\
\text { 区 } \\
\text { 合 } \\
\text { 計 }\end{array}$} & $\sim 1.5$ & $6 \%$ & $8 \%$ & $13 \%$ & 94 & $4 \%$ & 403 & $40 \%$ & $\sim 1.5$ & $13 \%$ & $9 \%$ \\
\hline & $\sim 3.0$ & & $6 \%$ & $15 \%$ & 5 & $6 \%$ & 320 & $32 \%$ & $\sim 3.0$ & & $11 \%$ \\
\hline & $\sim 6.0$ & & & $9 \%$ & 6 & $6 \%$ & 210 & $21 \%$ & $\sim 6.0$ & & \\
\hline & $\sim 12.0$ & & & $0 \%$ & 3 & $3 \%$ & 67 & $7 \%$ & $\sim 12.0$ & & \\
\hline & $12.0 \sim$ & & & & & $1 \%$ & 11 & $1 \%$ & $12.0 \sim$ & & \\
\hline & 計 & $6 \%$ & $14 \%$ & $37 \%$ & 23 & $20 \%$ & 1011 & $100 \%$ & 計 & $13 \%$ & $19 \%$ \\
\hline \multicolumn{9}{|c|}{ 〈近小・遗大〉 } & \\
\hline \multirow{8}{*}{$\begin{array}{l}\text { 大 } \\
\text { 㻥 } \\
\text { 区 }\end{array}$} & \multirow{2}{*}{\begin{tabular}{|l} 
近小の距離 \\
$(\mathrm{km})$
\end{tabular}} & \multicolumn{5}{|c|}{ 邀大の距離 $(\mathrm{km})$} & \multicolumn{2}{|c|}{ 計 } & 近大の距離 & \multicolumn{2}{|c|}{ 邉小の距離（km } \\
\hline & & \multicolumn{5}{|c|}{\begin{tabular}{l|l|l|}
$\sim 3.0$ & $\sim 4.5$ & $\sim 8.0$ \\
\end{tabular}} & \multicolumn{2}{|c|}{\begin{tabular}{l|l} 
実数 & 割合
\end{tabular}} & $(\mathrm{km})$ & \multicolumn{2}{|c|}{\begin{tabular}{|l|l|}
$\sim 3.0$ & $\sim 4.5$ \\
\end{tabular}} \\
\hline & $\sim 1.5$ & $1 \%$ & $2 \%$ & $8 \%$ & $13 \%$ & $9 \%$ & \multicolumn{2}{|c|}{$32 \%$} & $\sim 1.5$ & $19 \%$ & \\
\hline & $\sim 3.0$ & & $6 \%$ & $15 \%$ & $12 \%$ & $13 \%$ & 89 & $46 \%$ & $\sim 3.0$ & & $14 \%$ \\
\hline & $\sim 6.0$ & & & $8 \%$ & 79 & $4 \%$ & 37 & $19 \%$ & $\sim 6.0$ & & \\
\hline & $\sim 12.0$ & & & $1 \%$ & 19 & $1 \%$ & 3 & $2 \%$ & $\sim 12.0$ & & \\
\hline & $12.0 \sim$ & & & & 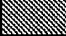 & $1 \%$ & 2 & $1 \%$ & $12.0 \sim$ & & \\
\hline & 計 & $1 \%$ & $8 \%$ & $31 \%$ & 32 & $28 \%$ & 193 & $100 \%$ & 計 & $19 \%$ & $17 \%$ \\
\hline & 近小の㭱離 & 連大の & 距離（1 & & & & & it & 近大の距離 & 遗小の! & 距離 $(\mathrm{kr}$ \\
\hline & $(\mathrm{km})$ & $\sim 3.0$ & $\sim 4.5$ & $\sim 8.0$ & $\sim 12$. & $12.0 \sim$ & 実数 & 割合 & $(\mathrm{km})$ & $\sim 3.0$ & $\sim 4.5$ \\
\hline$\neg$ & $\sim 1.5$ & $9 \%$ & $11 \%$ & $12 \%$ & 6 & $5 \%$ & 205 & $43 \%$ & $\sim 1.5$ & $17 \%$ & $13 \%$ \\
\hline 津 & $\sim 3.0$ & & $4 \%$ & $13 \%$ & 3 & $4 \%$ & 115 & $24 \%$ & $\sim 3.0$ & & $13 \%$ \\
\hline 区 & $\sim 6.0$ & & & $11 \%$ & 69 & $7 \%$ & 115 & $24 \%$ & $\sim 6.0$ & & \\
\hline & $\sim 12.0$ & & & $0 \%$ & 3 & $4 \%$ & 37 & $8 \%$ & $\sim 12.0$ & & \\
\hline & $12.0 \sim$ & & & & & $2 \%$ & 9 & $2 \%$ & $12.0 \sim$ & & \\
\hline & 計 & $9 \%$ & $15 \%$ & $36 \%$ & 18 & $22 \%$ & & $100 \%$ & 就 & $17 \%$ & $26 \%$ \\
\hline & 近小の距離 & 遠大の & 距離（1 & & & & & क्ञt & 近大の距離 & 遗小の! & 距離（k \\
\hline & $(\mathrm{km})$ & $\sim 3.0$ & $\sim 4.5$ & $\sim 8.0$ & $\sim 12$. & $12.0 \sim$ & 実数 & \begin{tabular}{|l|} 
割合 \\
\end{tabular} & $(\mathrm{km})$ & $\sim 3.0$ & $\sim 4.5$ \\
\hline & $\sim 1.5$ & $5 \%$ & $8 \%$ & $17 \%$ & 94 & $1 \%$ & 136 & $40 \%$ & $\sim 1.5$ & $8 \%$ & $7 \%$ \\
\hline & $\sim 3.0$ & & $8 \%$ & $18 \%$ & 5 & $4 \%$ & 116 & $34 \%$ & $\sim 3.0$ & & $7 \%$ \\
\hline & $\sim 6.0$ & & & $7 \%$ & 5 & $5 \%$ & 58 & $17 \%$ & $\sim 6.0$ & & \\
\hline & $\sim 12.0$ & & & $0 \%$ & 59 & $3 \%$ & 27 & $8 \%$ & $\sim 12.0$ & & \\
\hline & $12.0 \sim$ & & & & & $0 \%$ & 0 & $0 \%$ & $12.0 \sim$ & & \\
\hline 浜 & 詰。 & $5 \%$ & $16 \%$ & $42 \%$ & 245 & $13 \%$ & 337 & $100 \%$ & 計 & $8 \%$ & $14 \%$ \\
\hline 地 & & & & 近同. & 䢙同〉 & & & & & 同> & \\
\hline 区 & 近同の距離 & 逶同の & 距離 (1 & & & & & it & 距離（km) & 言 & th \\
\hline & $(\mathrm{km})$ & $\sim 3.0$ & $\sim 4.5$ & $\sim 8.0$ & $\sim 12$. & $12.0 \sim$ & 実数 & \begin{tabular}{|l|} 
㝬合 \\
\end{tabular} & & 実数 & 割合 \\
\hline & $\sim 1.5$ & $5 \%$ & $15 \%$ & $27 \%$ & $0^{\circ}$ & $0 \%$ & 19 & $46 \%$ & $\sim 1.5$ & 10 & $48 \%$ \\
\hline & $\sim 3.0$ & & $27 \%$ & $20 \%$ & 0 & $0 \%$ & 19 & $46 \%$ & $\sim 3.0$ & 8 & $38 \%$ \\
\hline & $\sim 6.0$ & & & $5 \%$ & 0 & $0 \%$ & 2 & $5 \%$ & $\sim 6.0$ & 2 & $10 \%$ \\
\hline & $\sim 12.0$ & & & $0 \%$ & 29 & $0 \%$ & 1 & $2 \%$ & $\sim 12.0$ & 1 & $5 \%$ \\
\hline & $12.0 \sim$ & & & & & $0 \%$ & 0 & $0 \%$ & $12.0 \sim$ & 0 & $0 \%$ \\
\hline & 計 & $5 \%$ & $41 \%$ & $51 \%$ & 2 & $0 \%$ & 41 & $100 \%$ & 総計 & 21 & $100 \%$ \\
\hline
\end{tabular}

近大・息小〉

\begin{tabular}{l|r|r|r|l|r|r}
\multicolumn{2}{l|}{} & \multicolumn{3}{|c}{ 〈等小・等大〉 } \\
\\
\end{tabular}
(近大・臬小)

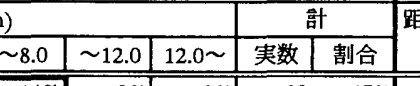

\begin{tabular}{l|l|l} 
& & \\
\cline { 2 - 3 } & 実数 & 割合 \\
\hline
\end{tabular}

\begin{tabular}{r|r|r|r|r|r|}
$\sim 8.0$ & $\sim 12.0$ & $12.0 \sim$ & 実数 & 割合 & \\
\hline $14 \%$ & $9 \%$ & $2 \%$ & 30 & $47 \%$ & $\sim 1.5$
\end{tabular}

\begin{tabular}{l|l|ll|l|l|}
$9 \%$ & $5 \%$ & $2 \%$ & $30 \%$ & $\sim 3.0$ \\
\hline
\end{tabular}

\begin{tabular}{ll|ll|l|}
$9 \%$ & $8 \%$ & 12 & $19 \%$ & $\sim 6.0$ \\
\hline
\end{tabular} $0 \% \quad 0 \% \quad 3 \% \quad 2 \quad 3 \% \sim 12.0$ $2 \% \frac{\sim 12.0}{12.0 \sim}$ \begin{tabular}{|r|r|}
\hline 10 & $24 \%$ \\
21 & $51 \%$ \\
\hline 9 & $22 \%$
\end{tabular} \begin{tabular}{|r|r|r|r|r|}
\hline & $2 \%$ & \multicolumn{1}{|c|}{1} & $2 \%$ & 12.0 \\
\hline $33 \%$ & $22 \%$ & $9 \%$ & 64 & $100 \%$ \\
\hline
\end{tabular}

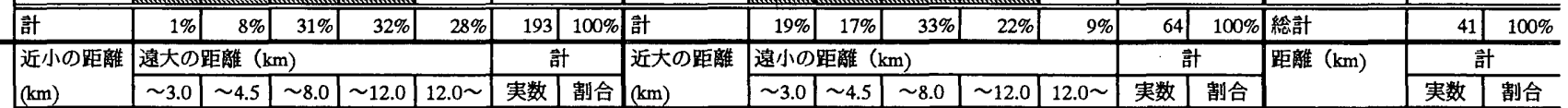

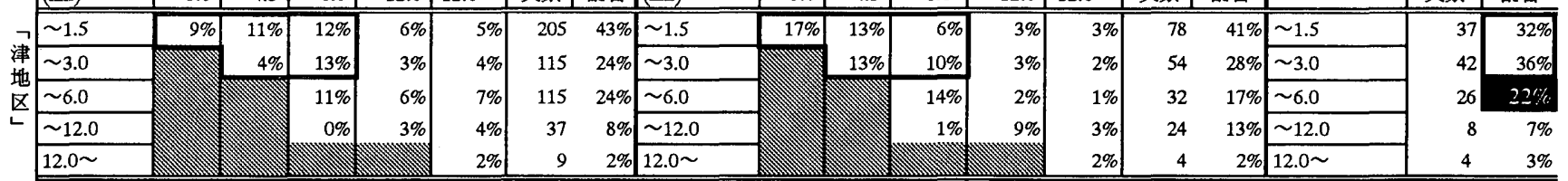

\begin{tabular}{|c|c|c|c|c|c|c|c|c|c|c|c|c|c|c|c|c|c|c|}
\hline \multirow{3}{*}{$\begin{array}{l}\text { 計 } \\
\text { 近小の距離 } \\
(\mathrm{km})\end{array}$} & $9 \%$ & $15 \%$ & $36 \%$ & $18 \%$ & $22 \%$ & \multicolumn{2}{|c|}{\begin{tabular}{l|l|}
481 & $100 \%$ \\
\end{tabular}} & \multirow{2}{*}{ 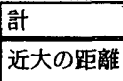 } & $17 \%$ & $26 \%$ & $30 \%$ & $17 \%$ & $11 \%$ & 192 & $100 \%$ & 紷言十 & 117 & $100 \%$ \\
\hline & \multicolumn{5}{|c|}{ 遗大の距離 $(\mathrm{km})$} & \multicolumn{2}{|c|}{ 計 } & & \multicolumn{5}{|c|}{ 遠小の距離（km） } & \multicolumn{2}{|c|}{ 計 } & \multirow[t]{2}{*}{ 距離 $(\mathrm{km})$} & \multicolumn{2}{|c|}{ 計 } \\
\hline & $\sim 3.0$ & $\sim 4.5$ & $\sim 8.0$ & $\sim 12.0$ & $12.0 \sim$ & 実数 & 割合 & $(\mathrm{km})$ & $\sim 3.0$ & $\sim 4.5$ & $\sim 8.0$ & $\sim 12.0$ & $12.0 \sim$ & 実数 & 割合 & & 実数 & 割合 \\
\hline$\widetilde{\sim 1.5}$ & $5 \%$ & $8 \%$ & $17 \%$ & $9 \%$ & $1 \%$ & 136 & $40 \%$ & $\sim 1.5$ & $8 \%$ & $7 \%$ & $19 \%$ & $2 \%$ & $3 \%$ & 70 & $39 \%$ & $\sim 1.5$ & 32 & $17 \%$ \\
\hline$\sim 3.0$ & & $8 \%$ & $18 \%$ & $5 \%$ & $4 \%$ & 116 & $34 \%$ & $\sim 3.0$ & & $7 \%$ & $23 \%$ & $3 \%$ & $2 \%$ & 62 & $34 \%$ & $\sim 3.0$ & 72 & $39 \%$ \\
\hline$\sim 6.0$ & & & $7 \%$ & $5 \%$ & $5 \%$ & 58 & $17 \%$ & $\sim 6.0$ & & & $12 \%$ & $9 \%$ & $4 \%$ & 45 & $25 \%$ & $\sim 6.0$ & 56 & $31 \%$ \\
\hline$\sim 12.0$ & & & $0 \%$ & $5 \%$ & $3 \%$ & 27 & $8 \%$ & $\sim 12.0$ & & & $0 \%$ & $0 \%$ & $1 \%$ & 2 & $1 \%$ & $\sim 12.0$ & 22 & $12 \%$ \\
\hline $12.0 \sim$ & 表 & & & & $0 \%$ & 0 & $0 \%$ & $12.0 \sim$ & & & & & $1 \%$ & 1 & $1 \%$ & $12.0 \sim$ & 1 & $1 \%$ \\
\hline 計 & $5 \%$ & $16 \%$ & $42 \%$ & $24 \%$ & $13 \%$ & 337 & $100 \%$ & 詁 & $8 \%$ & $14 \%$ & $53 \%$ & $14 \%$ & $11 \%$ & 180 & $100 \%$ & 縘計 & 183 & $100 \%$ \\
\hline
\end{tabular}

似た傾向が見られる。〈近同・遠同〉では、\{〈近同〉 $3.0 \mathrm{~km}$ まで\&〈臬同〉8.0kmまで\}の利用者数の累積は $90 \%$ を超え、

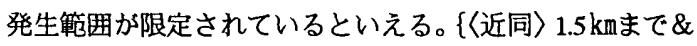
〈遠同〉 $8.0 \mathrm{~km}$ まで\} の利用者数の累積は $46 \%$ と半分近くに 達しており、その中には \{〈近同〉0〜 $1.5 \mathrm{~km} \&$ 〈遠同〉 4.5 $\sim 8.0 \mathrm{~km}$ と と〈近同〉 $1.5 \sim 3.0 \mathrm{~km} \&\langle$ 遠同〉 $3.0 \sim 4.5 \mathrm{~km}\lrcorner$ と

も $27 \%$ と多い。〈等同〉は〈等小・等大〉と似ており、 $3 \mathrm{~km}$

積は $12 \mathrm{~km}$ までも高い割合が続いている。これは、調查地域外の岐皁 県立図書館 (調查時点での蔵書は62.6万冊) からの影響が大きく、遠 く離れた大規模館の機能に応じて選択利用できるようになったと考え られる。

・「津地区」では、\{〈近小〉3.0〜 $6.0 \mathrm{~km} \& 〈$ 遠大〉 $4.5 \sim 8.0 \mathrm{~km}\}$ の利 用者累積は $11 \%$ と多く見られる。これは図書館の未設置町村があり、 近くに図書館がないため、利用者が 2 図書館までの利用距離とも遠い

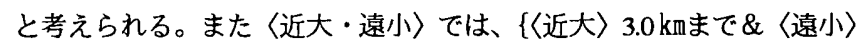
$4.5 \mathrm{~km}$ まで $〕$ 利用者数の累積は $43 \%$ となり、2 図書館までとも利用 距離が近い。津市にある津市図書館と三重県立図書館の 2 館は、津市 の利用者にとって利用距離が近いためである。

・「浜松地区」では、〈近小・遠大〉と〈近大・遠小〉とも $\{\langle$ 近〉0〜 $1.5 \mathrm{~km} \&$ \&遠〉 $4.5 \sim 8.0 \mathrm{~km}$ 、 \{〈近〉 $1.5 \sim 3.0 \mathrm{~km} \&\langle$ 遠〉 $4.5 \sim 8.0 \mathrm{~km}\}$ は $20 \%$ 前後と多い。〈等小・等大〉では $\{3.0 \sim 6.0 \mathrm{~km}\}$ は $31 \%$ あある。ま た「浜松地区」でしか見られない〈近同・遠同〉は〈近大・遠小〉に
までの利用者数の累積は〈等同〉全利用者の $86 \%$ となっている。「浜 松地区」では、浜松市にある中央館・分館の複数館設置に表れた複数 館利用の選択肢が豊かで、選択利用の形態が 3 地区で最も多い。

\section{3-3 選択利用の可能な圈域への考察}

（1）身近に図書館のある場合（図書館までの距離は $3 \mathrm{~km} 以 内 ）$

・距離 $8 \mathrm{~km}$ 以内に複数の図書館が設置された場合には、利用者を引 きつける選択利用が可能であるが、2図書館までの距離とも $3 \mathrm{~km}$ を超 える場合には、選択利用の起こる可能性が低い。即ち、選択形態に関 わらず、1 館までの距離は $3 \mathrm{~km}$ 以内で、他の 1 館までの距離は $8 \mathrm{~km}$ 内であれば、選択利用の起こる可能性が高いと考えられる。距離が近 くて利用しやすい施設を利用することにより、さらに多様な要求を求 めれば、遠い図書館を利用している実態が伺える。また距離 $3 \mathrm{~km}$ 以内 に複数図書館が設置された場合には、活発な選択利用が行われると推 測できる。

・とくに「大垣地区」に表れた岐皁県立図書館の施設規模に依存し 


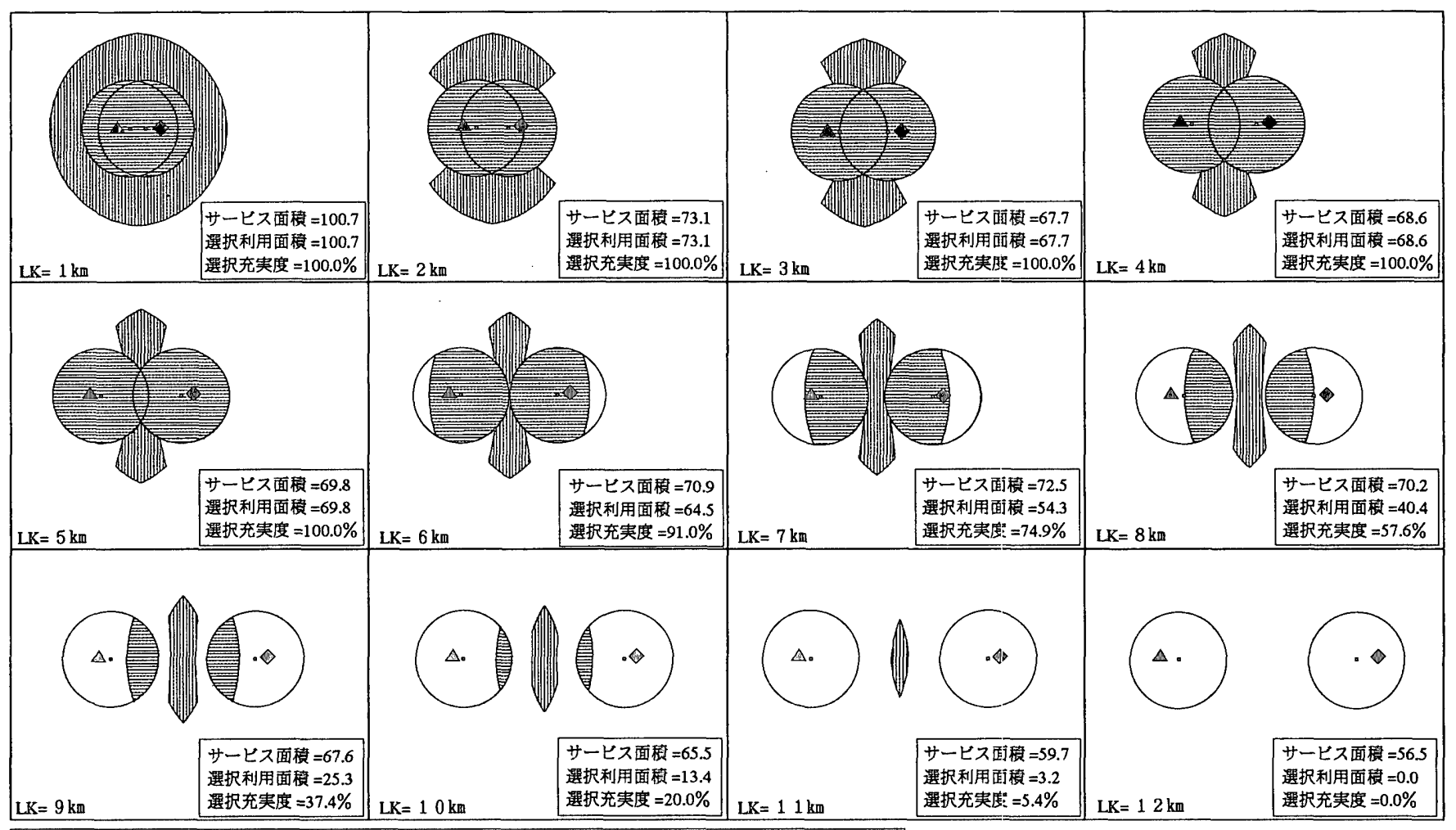

\begin{tabular}{|c|c|c|c|}
\hline & サーヒスス圈域 & & 単位 : km² \\
\hline 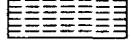 & サーヒスス圈域内の選択利用エリア & $\Delta \Leftrightarrow$ & 図書館サービスの特色 \\
\hline 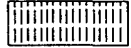 & サービス圈域外の遷択利用エリア & $\square$ & 図書館の位置 \\
\hline
\end{tabular}

ている傾向がある。即ち、モータリゼーションの発達により距離の抵 抗が弱まっており、遠く離れた大規模館の機能魅力に応して選択利用 が可能となっている。つまり大規模館であれば、距離は $12 \mathrm{~km}$ 程度ま で延びる可能である。

（2）身近に図書館のない場合（図書館までの距離は $3 \mathrm{~km}$ 以遠） 近くに図書館が設置されていない場合では、とくに〈等〉距離 $(2$ 図書館までの距離差が $1.5 \mathrm{~km}$ 以内)、かつ 2 館までの距離とも [3.0〜 $6.0 \mathrm{~km}\}$ の以内であれば、選択利用が起こる可能であると考えられる。

従って、選択利用が起こる可能性の高い圈域は以下のように整理で きる。

(1) $\mathrm{K} 1 \leqq 3 \mathrm{~km}$ 、かつ $\mathrm{K} 2 \leqq 8 \mathrm{~km}$ （大規模館の場合は $\mathrm{K} 2 \leqq 12 \mathrm{~km}$ ）

(2)また $3 \mathrm{~km}<(\mathrm{K} 1, \mathrm{~K} 2) \leqq 6 \mathrm{~km} 、$ かつ K $2-\mathrm{K} 1 \leqq 1.5 \mathrm{~km}$

(K1，K 2 は利用者の居住地からそれそれの 2 図書館までの利用距離）

\section{Q。䢧択利用モテルの作成}

単独館利用を計画前提 (以下: 単独利用モデル) として図書館の蔵 書冊数によりサービス圈域の広がりがすでに解明されていた注ら）。 こではその研究成果を参照し、広域の視点で複数図書館の選択利用を 促すことで、サービス面積・選択利用面積・選択充実度がいかに変化 しているかをシミュレーションする。

\section{Q.11。選択利用の成立然件}

・前報では、利用者が蔵書の充実性、距離の近さ、館内の空間環境 や立地環境の快適性、交通アクセスの利便性を求めて、図書館サービ スの特徴により選択利用を行うことを明らかにした。即ち、相互影響 を受け、かつサービスに特色ある複数図書館の存在は選択利用が起こ

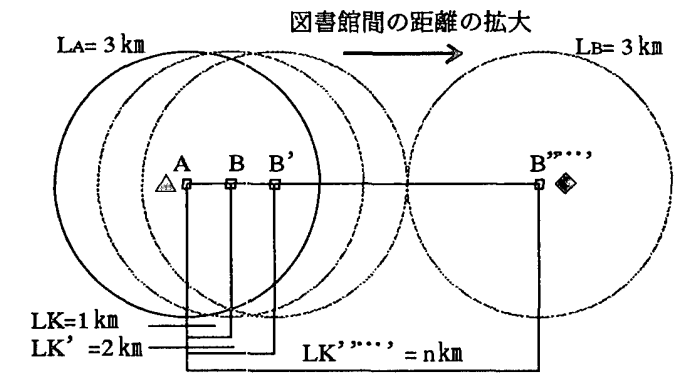

- 蔵兽冊数 $\mathrm{A}$ 館 $=3 \sim 5$ 万冊, $\mathrm{B}$ 館 $=3 \sim 5$ 万冊

・ サービス圈域 $\mathrm{LA}=3 \mathrm{~km}, \mathrm{LB}=3 \mathrm{~km}$

- 図兽館間の距離 $\mathrm{LK}=1 \mathrm{~km}, \mathrm{LK}^{\prime}=2 \mathrm{~km}, \cdots \cdot \mathrm{LK}, \cdots,=\mathrm{n} \mathrm{km}$

\四目费館サービスの特色田書館の位置

図 -1 モデル I 場合のシミュレーションの概念図

る前提条件である。

・単独利用モデルのサー・゙ス圈域でカバーされているエリアには図 書館サービスを受けていると考えれば、その圈域が重なり合うエリア には、利用者にとって利朋可能な図書館が多く、選択利用が起こる可 能であると考えられる。また、3章の分析結果を踏まえて選択利用の 発生条件を定める。つまり、

(1)単独利用を前提としたサービス圈域が重なっているエリア

(2) K $1 \leqq 3 \mathrm{~km} 、$ か $\mathrm{K} 2 \leqq 8 \mathrm{~km}$ (大規模館の場合は K $2 \leqq 12 \mathrm{~km}$ ) (3) $3 \mathrm{~km}<(\mathrm{K} 1, \mathrm{~K} 2) \leqq 6 \mathrm{~km}$ 、 2 つ $\mathrm{K} 2-\mathrm{K} 1 \leqq 1.5 \mathrm{~km}$

（K1,K 2 は利用者の居住地から 2 図書館までの利用距離）

以上の 3 条件のどれか咨満たせば、選択利用の起こる可能性が高い 
と考えられる 注 6)。

4-2. 選択利用の可能な圈域のシミュレーション

図書館の蔵書冊数により、大・中・小規模館をそれそれ 組み合わせてモデル I 〜 Vの 5 パターンを設定する。図-1 はモデルIを例として表したものである。

（1）モデル I は小規模館同士で、A 館と B 館の蔵書冊数 とも 3〜 5万冊、A館のサービス圈域 LA（以下： LA）とB 館のサービス圈域 LB (以下: LB) とも $3 \mathrm{~km}$ である。

（2）モデル II は中規模館同士で、A 館と B 館の蔵書冊数 とも5〜 7 万冊、サービス圈域LA と LB は $4.5 \mathrm{~km}$ である。

なお、地方都市圈において大規模館同士の場合が少ない ため省いた。

（3）モデルIIIは、小規模 $\mathrm{A}$ 館と中規模 B 館のような隣接 した町村立図書館（例えば「神戸」 4.5 万冊と「大野」 7.5 万冊）の蔵書差が少ない場合を対象としている。A 館の蔵 書冊数は $3 \sim 5$ 万冊、 LA は $3 \mathrm{~km} て ゙ 、 B$ 館の蔵書冊数は 5 〜 7 万冊、LBは $4.5 \mathrm{~km}$ である。

（4）モデルVI、さらに 2 図書館の規模差を拡大させ、周 辺にある小規模館と中心都市にある大規模館（例えば「神 戸」 4.5 万冊）と「大垣」 28.3 万冊や、「分館」と「中央館」 （例えば「可新」 5.8 万冊と「浜松中央」 40.2 万冊）のよう な小規模館のA館と大規模館のB館の蔵畫差が大きい場合 として設定したものである。ここでは、2図書館の藏書差 は 10 万冊以上で、A 館の蔵書冊数は $3 \sim 5$ 万冊、 LAは $3 \mathrm{~km}$

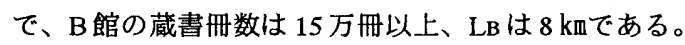

（5）モデルVは、中規模館と大規模館を対象としたもの である。中規模 $\mathrm{A}$ 館の蔵書冊数は 5〜 7万冊、LAは $4.5 \mathrm{~km}$ で、大規模 $\mathrm{B}$ 館の蔵書冊数は 15 万冊以上、LBは $8 \mathrm{~km}$ である。

なお、 5 モデルとも図書館間の距離（以下：LK）は $1 \mathrm{~km}$ からスタートし、1 kmずつを拡大させ、図-19モデル I を 例に示したように図面上で選択利用範囲を描き、サービス面積・選択 利用面積・選択充実度を求める。また同時に単独利用モデルと比較す るために、選択利用モデルと同様な方法で、単独利用モデルの各指標 值を求め、図書館間の距離の変化に対して各指標值の変動も考察す る。

\section{5. 選択利用モテルの各指標の変化（図 -2）}

\section{5-1. 図書館間の距離からみた各指標値の变化}

（1）モデル I 場合の各指標值の変化

モデル I では、サービス面積が LK3 kmまで減少しているか、その

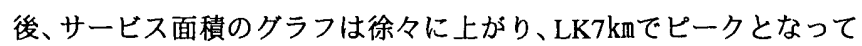
いる。また LK3〜10kmでサービス面積の変化が少なく、グラフが横 ばいとなっている。選択利用面積の変化が LK3 kmまで減少している

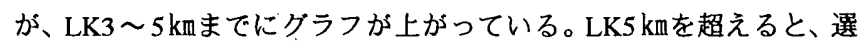
択利用面積が LK1 kmこととに $15 \mathrm{~km}^{2}$ 程度で再び減少している。LK12 km で選択利用面積が 0 となっている。選択充実度がLK5 kmまで $100 \%$ で、 その後、急激に減少している。LK10 kmを超えると、選択充実度は僅 か数パーセントである。

（2）モデルII場合の各指標值の変化

モデルIIでは、サービス面積が LK2 kmから増え続いており、LK10 km

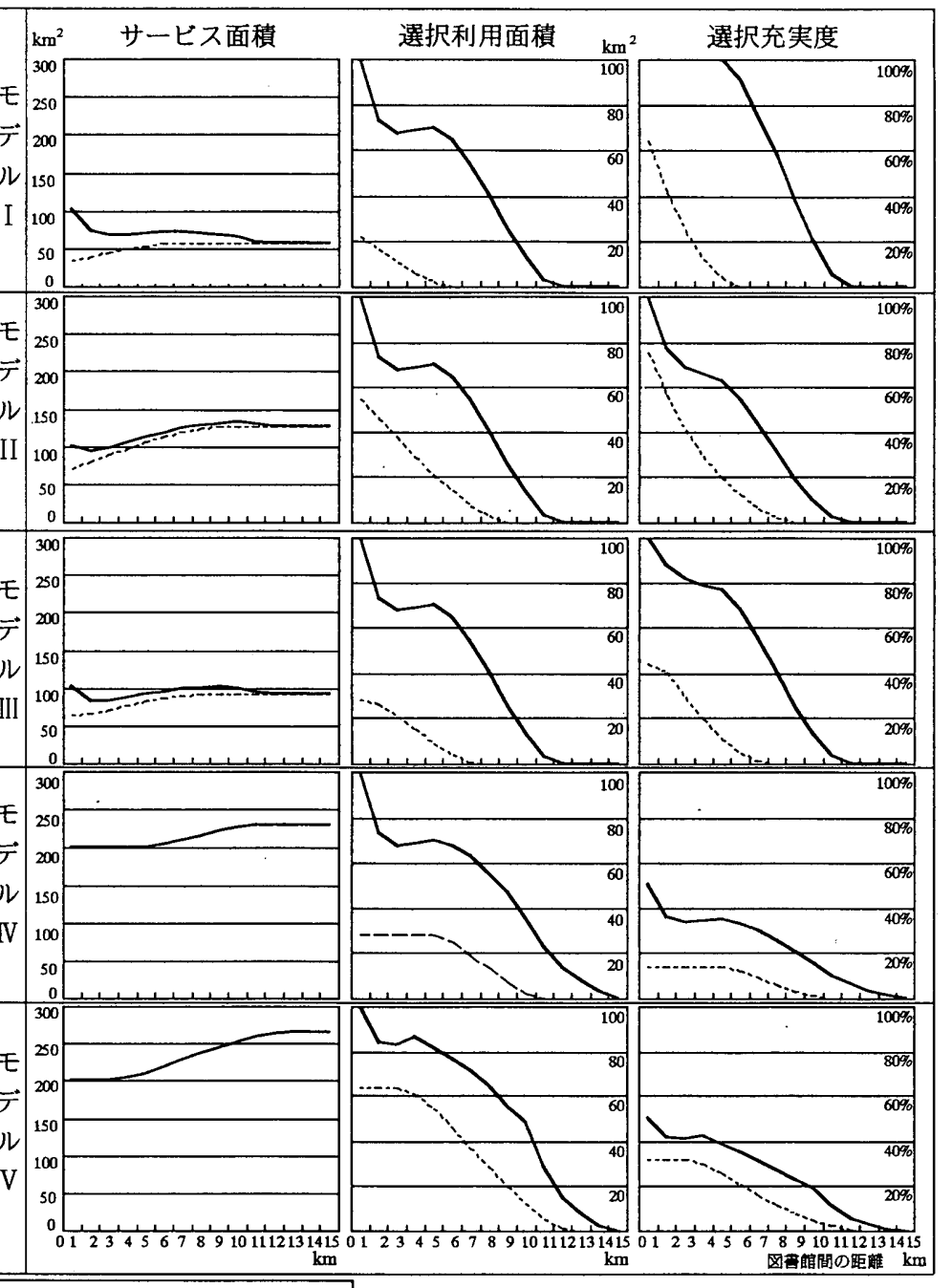

選択利用モデル場合 単独利用モデル場合

図 -2 各指標値の変動

でピークとなっている。選択利用面積のグラフが LK5 kmでピークと なっており、LK5 kmを超えると下がっている。図書館間の距離が離れ ると共に、選択充実度が減少しているが、LK3〜 $5 \mathrm{~km}$ の間に選択充実 度のグラフ勾配が緩やかである。

(3) モデル III場合の各指標值の変化

モテルIIIのサービス面積が LK2〜9kmにおいて増えつつあり、LK9 km を超えると減少している。LK7〜 $10 \mathrm{~km}$ の間には、サービス面積が大 凡 $100 \mathrm{~km}^{2}$ で、グラフが横ばいとなっている。選択利用面積と選択充 実度のグラフとも、LK5 kmでピークとなっており、また LK3〜 $5 \mathrm{~km}$ ではグラフの変化が少なく、横ばいとなっている。

（4）モデル N 場合の各指標值の変化

モデル IVのサービス面積が $200 \mathrm{~km}^{2}$ を超える高值が見られる。LK $5 \mathrm{~km}$ までサービス面積の変化がないが、その後、LK11 kmまで徐々に上 がっている。選択利用面積や選択充実度が図書館間の距離の拡大に よって減少しているが、LK3〜 7 kmの間にグラフの勾配は緩やかで、 值の変化が少ない。

（5）モデルV場合の各指標值の変化

モデルVのサービス面積が図書館間の距離の拡大とともに増えつつ あり、LK9 kmを超えると、サービス面積が $250 \mathrm{~km} 2$ 以上の高值となって いる。選択利用面積が LK4 kmでピークとなっており、その後、選択 


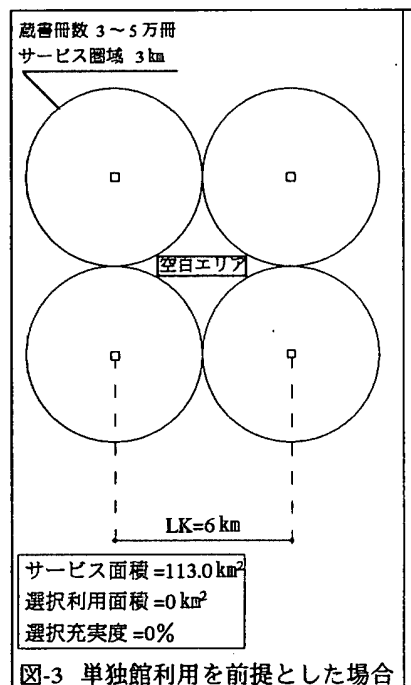
均㗨的分散配置の利用圈域

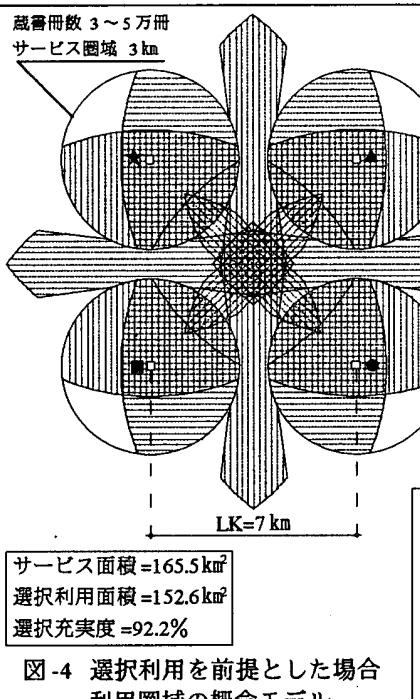
利用圈域の概念モテル
利用面積が減少しつつある。LK10 kmまでグラフの勾配が緩やかであ るが、LK10 kmを超えれば、選択利用面積は LK10 kmでの $50 \mathrm{~km}^{2}$ から 急激に数 $\mathrm{km}^{2}$ まで減少している。選択充実度のグラフ変化が選択利用 面積とよく似た傾向である。

5-2. 藏轰規模差からみた各指標值の変化

(1) サービス面樌

2 図書館の蔵書規模差を大きく設定したモデル Nとモテル Vには、 サービス面稳が蔵書規模差の少ないモデル I 〜 III (規模差は 2 万冊以 下）に比ベ、サービス面櫝が倍以上の高い值となっている。サービス 面稳のグラフからみると、モデル I 〜 IIIのサービス面樌は LK3 km 付 近で下がって、その後、図書館間の距離の拡大とともに、サービス面 積があがっているが、LK9 km前後（モテル I はLK7 kmまで）で再び 下がっている。また LK3〜 7 kmにおいて、モデルIIIのグラフ勾配が. モデル I ・IIに比べ急である。蔵書規模差を大きく設定したモデル $\mathrm{IV} \cdot \mathrm{V}$ のサービス面積は、図書館間の距離により增加する一方である が、最も蔵書規模差の大きいモデルIVのグラフ変化が少ない。

（2）選択利用面積

選択利用面樌の変化は蔵書規模差にかかわらず、図書館間の距離の 拡大に伴い、一方的に減少する傾向が見られる。蔵書規模差の大きい

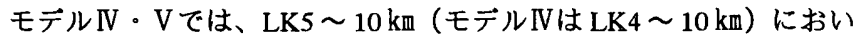
て、選択利用面積のグラフ減衰が緩やかである。また、最も蔵書規模 差の大きいモデルIVのピーク值は他のモデルに比べ高い。モデル I 。 II・IIIのグラフは、同じ形となっている。

\section{（3）選択充実度}

蔵書規模差の大きいモデル $\mathrm{N} ・ \mathrm{~V}$ の選択充実度がモデル I ・ II ・ III に比べて低い。モデルIVのグラフ勾配が、モデル I とモデル II に比べ 緩めであり、特にLK3〜 7 kmにおいて選択充実度が 30\%前後と変化 が少ない。

\section{3. 選択利用・単独利.用モデルの各指標值の比較}

図-2 から選択利用モデルと単独利用モデルとの 2 モデルの各指標 差をみると、3 指標とも選択利用モデルの値が高い。

（1）中小規模館の同士場合

小規模館同士 (モデル I の場合)では、各指標差が中規模館図書館 同士 (モデル II の場合) に比べ顕著であり、サービス面穦差が LK7 km

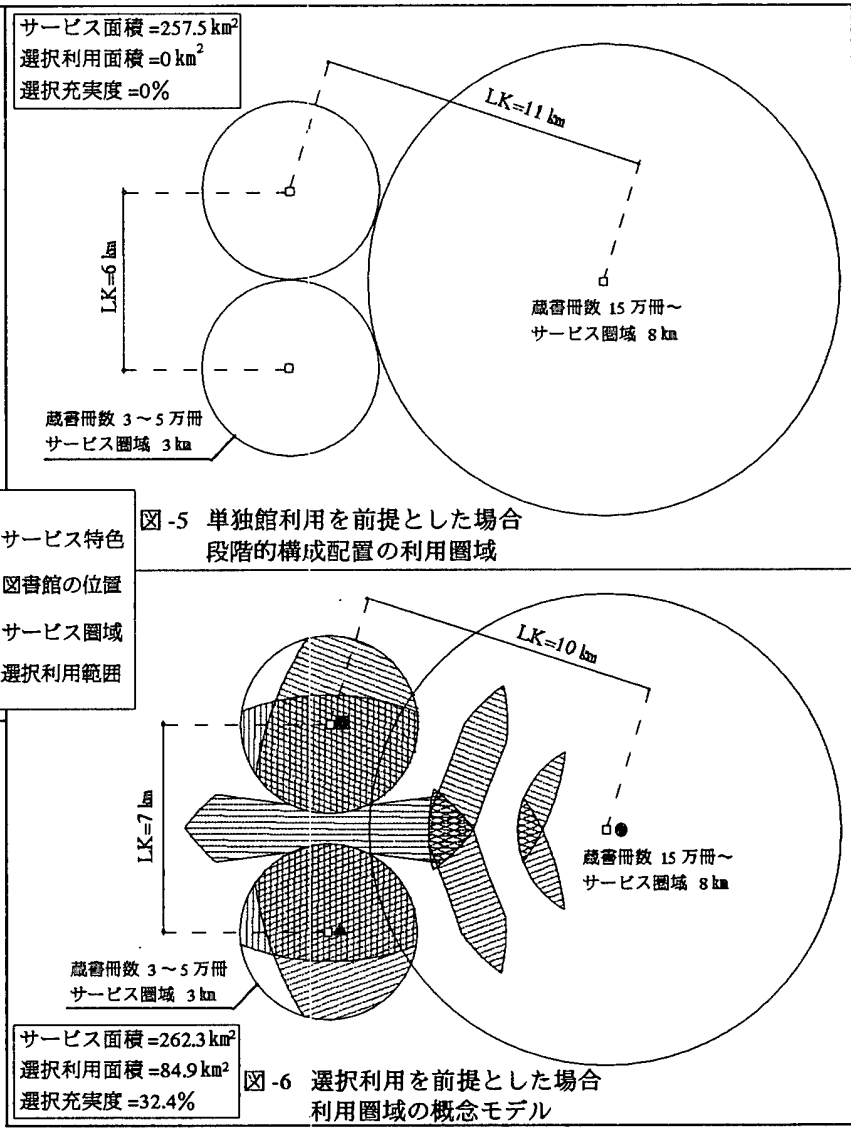

で、選択利用面穓と選択充実度の差がLK5 kmでピークとなっている。 中規模館同士の場合では、サービス面積差が LK7 kmでピークと なっているが、(LK3 km以遠）図書館間の距離によってサービス面矰 差の変化が著しくないといえる。また、選択利用面積と選択充実度が LK6 k四でピークとなっている。

（2）蔵書規模に大きな差のある場合

蔵書規模差のある場合では、選択利用を促してもサービス面積を增 やす効果が少なく、とくに蔵書規模差が大きい小規模館と大規模館、 あるいは中規模館と大規模館の場合ではサービス面稳差が0となって いる。しかし、選択利用モデルに比ベ、単独利用モデルの選択利用面 樌は少なく、選択充実度も低い。

各モデルの変化をみると、モデルIIIでは、 2 モデルのサービス面䅐 差が LK9 kmでピークとなっており、選択利用面積と選択充実度の差 が LK5 $5 \mathrm{~km}$ を超えると隇少している。最も蔵書規模差の大きいモデル IVでは、2 モデルの選択利用面積と選択充実度の差が $\mathrm{LK} 7 \mathrm{~km}$ 付近で ピークとなっている。中規模館と大規模館のモデルVでは、両モデル の選択利用面積と選択充実度の差が LK10 kmまで上昇し、その後急激 に減少している。

以上で述べたように、L.K1 km以内に複数館設置を設置すれば各指標 とも高い值が現れているが、地方都市圈において実現は困難である。 ゆえに、最大効率を図るために選択利用を計画前提として考えると、

・サービス面積の拡大を図るために、まずモデル $\mathrm{I} ・ \mathrm{~V}$ のように大 規模館と小規模館、あるいは大規模館と中規模館という図書館間の蔵 書規模差を増やし、図書館間の距離を $10 \mathrm{~km}$ まで広げることが考えら れる。また、モデル I 〜IIIのように中・小規模館同士、あるいは中規 
模館と小規模館の場合では、図書館間の距離を $7 \mathrm{~km}$ 前後と設定すれ ば、サービス圈域が最も広がると考えられる。

・図書館サービスの充実性を考えると、図書館間の距離を $5 \mathrm{~km}$ 前 後と設定すれば、選択利用の起こりうる圈域が広くなり、選択充実度 が高くなるといえる。

・また、大規模館を絡んでいる場合、とくに大規模館と小規模館の 蔵書規模差が大きい場合では、図書館間の距離を $10 \mathrm{~km}$ まて広げても 選択充実度が $20 \%$ とやや高いとみられる。

\section{6. 選択利用に基づいて配置計画論への展開}

\section{6-1. 既往配置計画論との比較}

\section{（1）均質的分散配置計画}

近さが図書館利用を惹きつける主な要因であると考えると、身近に 全ての地域住民に平等で図書館サービスの提供を図るために均質的 (一定の蔵書規模) 分散配置は理想的な配置モデルである。このモデ ルの成立条件としては、施設間の相互影響を無視できることと、高密 度な施設配置と一定のサービス水準の確保が必要である。

しかし図-3に示したように、サービス圈域の一部重複をさせない と、均質的分散配置でもサービス圈域の間に図書館サービスを提供で きないサービス空白のエリアが存在しているため、全ての地域住民に サービスの提供は理論上で困難である。また図書館間の距離が $10 \mathrm{~km}$ 以内であれば、相互影響を受けており文2)、人口密度が低くかつ人口 分布が偏っている地方都市圈において隣接した市町村立図書館は中小 規模館が多く、分館を持つことが少ない。つまり、地方都市圈では高 密度な施設配置に頼ることが困難である。

図-4からみると、小規模館であってもそれそれの図書館サービス の特性を持ち選択利用を配慮すれば、図書館間の距離を LK7 kmまで 広げてもサービス面積は $165.5 \mathrm{~km}^{2}$ となり、単独利用モデル（図-3） に比べ50\%のサービス面積も拡大される。選択利用面樌も0から $152.6 \mathrm{~km}^{2}$ まで増え、選択充実度は $92.2 \%$ と高くなっている。選択モテ ルにより圈域面積を算定することで、選択利用を促すことはサービス 面積の拡大やサービスの充実性を図ることに効率的であると考えられ る。またサービス面樻を考えれば、必ずしも $3 \mathrm{kmことに} 1$ 館を設置す る必要がない。つまり高密度な施設配置に頼らなくてもサービス面䄼 の拡大やサービス充実性の改善ができると考えられる。

\section{(2) 段階的構成配置}

図書館の段階的構成配置といえば、中央館と分館という図書館シス テムと、県立図書館あるいは広域をサービス対象となる中心館(例え ば大規模館「津」) と市町村立の地域館という図書館ネットワークの 2パターンがある。どちらも来館距離とサービス水準（蔵書規模）に よって図書館を段階的に配置され、利用者が近くにある小規模図書館 を利用し、さらに高度な利用要求であれば遠くにある中央館或いは地 域中心館を利用するという S.B. 現象によって想定したものである。 即ち、図-5に示したように図書館の配置的には分散で、機能的には 集中であるといった配置モデルである。しかし「浜松地区」のような 複数館設置地域では、必ずしも近くのある分館を選択利用するのでは なく、直接に遠くにある機能充実した中央館を利用するケースが多く 見られ、中央館を利用せず分館同士の使い分けの利用も多い。また 「津地区」のような図書館ネットワークにあっても近隣の図書館を飛 び越えて遠距離の「津」や「三重県立」を利用することも少なくない。
多様化している要望にあわせて利用者が図書館を選択利用し、必ずし も段階的構成とはなっておらず、S.B. 現象はさらに複雑となってい る。

選択利用を促すことを考えると、図-6のようにまず中心館（中央 館）と地域館（分館）間の距離を $10 \mathrm{~km}$ 以内に置き、2図書館の相互 影響をさせる。地域館 (分館) の間の距離を $7 \mathrm{~km}$ に配する。サービス 面積は $262.3 \mathrm{~km}^{2}$ となり、選択利用面積は $84.9 \mathrm{~km}^{2}$ まで拡大される。単 独利用モデルに比べ、サービス面積の増加が $5 \mathrm{~km}^{2}$ とわずかであるが、 選択利用面積と選択充実度の増加が顕著である。即ち、大規模館が存 在している地域においては周辺にある中小規模館との連係をさせ、 サービス圈域の拡大を図るべきである。また中小規模館においても単 なる大規模館に頼るのではなく、特色ある施設整備によりトータルの サービス充実性の改善を図ることが実現できると考えられる。

\section{6-2. 図费館眍置計画への展開}

（1）選択利用を計画前提とした意義

選択利用に基づいて広域的視点で資料収集・資料保存・施設的整備 などは自治体の枠組みにとらわれなく、少量かつ分散した資源がトー タルに計画されるため、利用者が一定の施設サービス水準以上の享受 を得ることができる。即ち、最小規模で最大効率を実現できると考え られる。

（2）配置計画の指針

地方都市圈においては施設密度が疎であるため、図書館配置計画は まずサービス圈域の拡大を図ることを考えるべきである。10 km以内 に図書館サービスに特色のある複数館 (2 館以上) を整備し、選択肢 の確保によってサービス圈域を拡大する。具体的には、

・サービス水準の高い大規模図書館が整備できる地域(例えば中心 都市が明確に存在する地域)には、(図-6のように)その周辺 $(10 \mathrm{~km})$ までにある図書館と連係させ、周辺には隣接した図書館間の距離を $7 \mathrm{~km}$ に配置し、サービスに特色のある図書館を整備する。

・中小規模館が中心となる地域には、（図-4のように） $7 \mathrm{kmことに}$ サービスに特色のある図書館を整備する。

サービス水準の高い大規模図書館が設置できるかどうかに関わら ず、特に $7 \mathrm{~km}$ ごとにサービスに特色のある中小規模館を整備する目標 は現実的な図書館整備の方向であると考えられる。

また、図書館がすでに整備され施設密度が高い地域には、図書館 サービスの充実性を図り、即ち利用者が一定のサービス水準以上を得 る可能と考えると、 $5 \mathrm{~km}$ 以内ことにサービス特色のある図書館を整備 することも重要である。これは、地方都市圈のみでなく大都市にも適 用すると推測できる。

\section{7.まとめと今後の課通}

本研究は地方都市圈において効率的な地域施設の配置計画のため に、選択利用に着目して解析、提案したものである。選択利用に着目 することは、いわゆる図書館そのものの存在価值が問われている様子 が伺え、利用者が現存の図書館サービスをいかに認識しているかが把 握できるため、現状の改善及び今後の図書館計画への指針を探り出す には重要な意義を持っていることが分かった。まとめると、

・複数館の選択利用が起こる可能性の高い範囲を明らかにした。す なわち、

(1) $\mathrm{K} 1 \leqq 3 \mathrm{~km}$ 、かつ $\mathrm{K} 2 \leqq 8 \mathrm{~km}$ （大規模館の場合は $\mathrm{K} 2 \leqq 12 \mathrm{~km}$ ） 
(2) $3 \mathrm{~km}<(\mathrm{K} 1, \mathrm{~K} 2) \leqq 6 \mathrm{~km} 、$ かつ $\mathrm{K} 2-\mathrm{K} 1 \leqq 1.5 \mathrm{~km}$ となる。 •試案的モデルの検討により選択利用ができる複数図書館の共存し ている地域では、サービス圈域が単独利用モデによるものより大き くなる。つまり、選択利用を促すことによって図書館サービスを受け る圈域が拡大でき、サービスの充実性を高めるのが可能である。

・図書館規模 (蔵書冊数)によってサービス圈域が異なるか、要約 すれば約 $7 \mathrm{~km}$ １0 kmことにサービスに特色のある図書館が配置され る場合にサービス効率が最も高くなる。

・地域住民にとって選択できるという意味で多様化した利用要求に 応え、図書館サービスの水準を引き上げ、広域の全体として図書館 サービス水準を向上できる。選択利用に基づく配置計画の手法が効率 的であり、その有効性が検証できた。

・本論文では図書館のサービス特性により選択利用の可能な圈域の 広がりについては定量的に提示できていない。今後の課題としては、 とくに空間環境のサービス特色により利用圈域の広がりを定量的に捉 えて検討する必要がある。

・選択利用モデルは概念的に扱われ、配置計画の方法論としてモデ ルの有効性を検証したが、地域範囲や地形変化などの地域特性によっ てモテルの効率性をさらに分析する必要がある。

・施設密度 (施設間の直線距離) と施設サービスの特色により複数 館の選択利用が起こる可能性の高い範囲を 2 次元座標空間にシミュ レーションし検証した。結果としては、島状のような極端な範囲と なっている。現実的には複数施設の選択利用の発生率によりその形は もっとなめらかで広䉇囲のものであると予測している。理論を補完す るために、今後研究事例を增やし、選択利用の発生率によりデー夕を 再分析し、3次元座標空間に連続的に図示し、数学的に検討する。さ らに複数館の選択利用に影響を与える総合的要件を整理し、選択利用 構造モデルを概念的に構築する。

・複数図書館の選択利用に基づく利用圈モデルを検討し、モデルの 効率性を概念的に明らかにしたか、理論の完成や実務的活用までには 至っていない。その理由の一つは、疎住地のみを研究対象としたもの であり、地域性がモデルに十分反映されていないためである。フィー ルドと異なる社会情況にある大都市を研究対象とし、複数図書館の選 択利用現象が捉えられる仮説の妥当性を検証し、複数施設の選択利用 の理論完成や活用方法の確立や、既存の地域施設配置計画論に新機軸 を提出することを目指している。

本論文は2003年の第21回地域施設計画研究シンボジウムにおいて発表論文を基に 加筆したものである。文4）参照。

副辞

調查に快くこ協力していたたいた各図書館の館長をはしめ賳貝の方々、来館者の 方々に深く感謝いたします。調莶に参加していたたいた三重大学今井研究室各位、調 亘内容に開するアドバイスをいたたいた中井孝幸氏、分析に協力をいたたいた架田直 子氏、森下克也氏、大前裕街氏、三輪恭子氏、熊谷健太郎氏に感謝の意を表します。

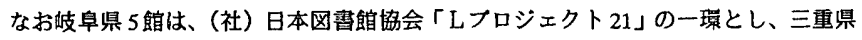
9館は、津地区広域行政組合の共同研究の一部として行いました。関係各位に樑謝い たします。

注毁

注 1）例えば、墨原嘉一郎氏らは大阪府枚方市などを事例にし、来館者密度比 0.1 と 0.2 保障の場合、分館を分散的に配置する図書館網計画がある。文7)

注2）例えば、中村恭三氏らは図書的自の規模（蔵書冊数）に応して大中小型館に分け、 館規模別に受持の人ロメッシュエリアが異なる広域の四書館網計画がある。文8）

注3）選択された A館・B館を距雄と蔵畫冊效でそれそれ比皎し、以下のように選択 形態に整理した。

$A$ 館蔵書冊数 $-B$ 館蔵襾冊数 $>1$ 万冊

$\rightarrow \mathrm{A}$ 館は相対的〈大〉規模、B 館は相対的〈小〉規模
$A$ 館蔵書冊数 $-B$ 館蔵䡒冊数 $\leqq 1$ 万冊 $\rightarrow A$ 館と B 館は相対的〈同〉規模 $\mathrm{A}$ 館まで距離一 $\mathrm{B}$ 館まで距離 $>1.5 \mathrm{~km}$

$\rightarrow \mathrm{A}$ 館は相対的〈息〉距離、B 館は相対的〈近〉距䧹 $\mathrm{A}$ 館まで距離一 $\mathrm{B}$ 館まで西離 $1.5 \mathrm{~km} \rightarrow \mathrm{A}$ 館と $\mathrm{B}$ 館は相対的〈等〉距離 それそれ組み合わせると、〈近小・遗大〉〈近大・遗小〉〈等小・等大〉〈近同・息 同〉〈等同〉の計 5 選択パターンとなる。なお、〈近同・遠同〉や〈等同〉が「浜 松地区」しか見られない。文1）参照。また、とくに説明のない場合は〈〉を 相対的な意味にし、絶対的な規模や距離的遑近の概念と区別する。

注4）距離区分については、とくに本研究と関係ある中井孝幸氏の研究成果を参照し た。中井氏は地方都市（徚住地）における図書館の利用圈域を研究し、1.5k四の 館近傍までは距離の尉罊を受けやすく、高い来館率 (町丁字の地区人口 1000 人

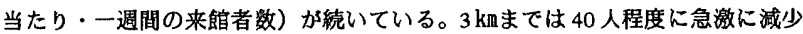
し、その後は町部で 6 8 km、市部では $10 \sim 12 \mathrm{~km}$ まで 20 人弱の来館率が緩や かに続き、0人に収束している。つまり、利用者にとって距離 $1.5 \mathrm{~km}$ 超えると 距離感が感じられるため、2図書館までの距離差を $1.5 \mathrm{~km}$ 設定した。また来館 率や図書館の規模と利用距離との関係（注5）を配慮し、来館率に影眯を与える 距㕍は $1.5 \mathrm{~km} 、 3.0 \mathrm{~km} 、 6.0 \mathrm{~km} 、 8.0 \mathrm{~km} 、 12.0 \mathrm{~km}$ となっていると考えられる。文10-12）

注5) 中井孝幸氏は、蔵書割合（当館の蔵書冊数を $8 \mathrm{~km}$ 以内にある困書館の蔵書冊数 の合計であるもの) を地㖪特性とし、蔵書割合 0.3 (㬽查した 16 䬼のほぼ平均 值）を基舫として藏書冊数と来館率 10 人までの伸びる距離（利用圈域）との関 係を明らかにした。即ち、 3 万冊は $3 \mathrm{~km}$ まで、 $5 \sim 7$ 万冊は $4 \mathrm{~km}$ 以上、 15 万冊以上は $8 \mathrm{~km}$ 以上となっている。文 11$)$

注6）選択利用が起こる圈域は、発生率によって連続的分布であると考えられる(下図)。 本研究は選択利用の効果を゙検証するために、まず選択利用の発生率が高い圈域を平 面に図示し検討する。

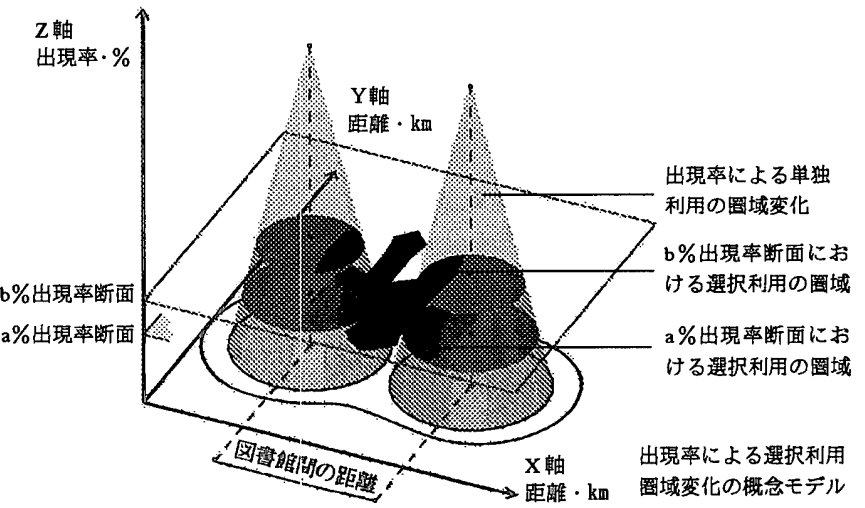

参㴗文献

文1）丁圆、今井正次、中井录幸 : 襀数図書館の選択利用の諸要件に関する研究 - 施 設の選択利用を促す地方㰾市における图書館計画に関する研究1 日本建策学会 計画系論文集 第 557 号 pp.173-179, 2002.7

文2）丁圆、今井正次、中井素幸 : 選択利用の地域特性 - 地方都市における地域施設 配置計画に関する研究 日本建策学会地域施設計画研究 20 pp.7-14, 2002.7

文3）丁圆、今井正次、中井录幸：選択利用に適した施設の空間摆境要求 - 地方都市 の四彗館計画に関する研究 日本建築学会地域施郡計画研究20 pp.77-84, 2002.7

文4）丁圆、今井正次 : 選択利用に基づく図書館配置計画 - 地方都市圈において選択 利用を促す図畫館計画に関する研究 日本建築学会地域施能計画研究21 pp.225$234,2003.7$

文5）渡辺光雄：地域計画に䚷ける公共施設の設䈯計画に関する研究-S.B. 現象につ いて 1 日本建築学会計画系論文集 第 326 号 pp.126-134, 1983.4

文6）洨辺光雄 : 地域計画に扮ける公共施設の設置計画に閣する研究-S.B. 現象につ いて2 日本建築学会計画系論文集 第 334 号 pp.148-157, 1983.12

文7) 栗原嘉一郎、簙塚宏三、中村恭三、高山司郎 : 図書館網計画のケーススタティ－ 公共図書館計画に関する研究·8 日本建築学会諭文報告集 第228号 pp.40-47, 1989.1

文8）中村恭三、栗原嘉一郎：広域に対する困書館網計画に関する研究 - 新・公共困 書館の設置計画に関する研究·12 日本建築学会論文報告集 第512号 pp.123-130, 1998.10

文9）植松貞夫、谷村秀彦、河村芳行 : 複数図書館設置都市における区毒館利用登録 者の利用行動 日本建築学会計画系論文集 第395号 pp.40-47, 1989.1

文10)中井孝幸、今井正次 : 地方都市における図書館の利用圈域の二重㛵造 - 疎住地 の地域施設の設置計画に関する研究・1 日本建築学会計画系論文集 第 482 号 pp.75-84, 1996.4

文11)中井孝幸、今井正次 : 地方都市における施設サーヒス水洀と図書館の利用圈域 楆造-疎住地の地域施設の設置計画に関する研究・2 日本建築学会計画系論文集 第 508 号 pp.75-82, 1998.6

文12)中井孝幸 : 利用圈域の二重棈造に基つくく疎住地の図書館計画に関する研究 学位論文 三重大学, 2000.7

（2003年 7 月 7 日原稿受理，2003年11月25日採用決定） 